\title{
Resistência e resiliência em tempos de pandemia
}

Até o dia que redijo esse editorial, mais de 80.000 famílias brasileiras já haviam perdido seus entes queridos para a COVID-19. Pessoas de todas as idades tiveram suas trajetórias interrompidas e nem mesmo uma despedida digna lhes foi possibilitada. Por respeito a essas famílias, não há de se falar em consequências positivas dessa pandemia.

No entanto, escrevo sobre resistência e resiliência em tempos de pandemia. E para isso, destaco três conceitos que sairão dessa pandemia ainda maiores do que nela entraram: Ciência, Universidade e Sistema Único de Saúde. Comecemos pela ciência: resiliência, porque mesmo com a redução progressiva dos investimentos em ciência e tecnologia no Brasil, nossos cientistas seguem envolvidos em pesquisas sobre vacinas, medicamentos, testes, estudos epidemiológicos, avaliação das desigualdades em saúde, entre outros; resistência, porque tudo isso é feito num momento em que o negacionismo e a imbecilidade se banalizaram tanto, que dizer que a terra é plana parece natural.

Um ano atrás, num ato de resistência, as Universidades foram às ruas protestar contra um bloqueio orçamentário que inviabilizava seu funcionamento. E mesmo subfinanciadas, tendo sido difamadas como local da "balbúrdia", as Universidades seguiram firmes, e num ato de resiliência, produzem diariamente conhecimento sobre a COVID-19, e dão alento para uma população justificadamente aterrorizada, pela falta de uma liderança nacional que promova a paz, e não a guerra, entre aqueles que pensam diferente.

Tão subfinanciado e difamado quanto a ciência e as Universidades, o SUS está impedindo que a tragédia seja ainda maior. Num ato de resistência, o sistema tem conseguido prestar atendimento a todos os brasileiros com COVID-19 que dele dependem. Nem todos os pacientes são salvos, é verdade, mas diferentemente do ocorrido em outros países, o SUS não entrou em colapso, e mitiga um desastre que poderia ser muito maior. Um SUS que, com resiliência, acolhe as pessoas, mas, especialmente, um SUS composto por profissionais de saúde resistentes e resilientes, que colocam a saúde coletiva acima das dificuldades e seguem prestando atendimento aos brasileiros que dele necessitam.

Pela segunda vez, em um curto espaço de tempo, a Ciência \& Saúde Coletiva publica um número especial com artigos sobre COVID-19, confirmando que a ciência brasileira não está de braços cruzados. Nesse mesmo período, a Universidade Federal de Pelotas (UFPel) colocou na rua o EPICOVID19, um projeto que demoraria um ano para ser planejado. Interessante fazer dois links entre o EPICOVID-19 e as origens do grupo de Epidemiologia da UFPel. O primeiro é que, tanto o estudo sobre mortalidade infantil que deu origem à coorte de 1982, quanto o EPICOVID-19, inspiram-se numa questão de pesquisa semelhante: as estatísticas oficiais podem não estar mostrando a real dimensão do problema.

No Rio Grande do Sul, já foram conduzidos seis inquéritos sorológicos e amostra total de 27.000 pessoas, e mais dois ainda serão realizados ${ }^{1}$. Embora o percentual da população com anticorpos no estado ainda seja próximo de $1 \%$, há uma diferença marcante entre o número de casos notificados e o número de pessoas que já tiveram exposição ao vírus ${ }^{2}$. No Brasil, três inquéritos sorológicos com intervalo de duas semanas foram realizados, incluindo, no total, quase 90.000 brasileiros. É nos resultados do estudo nacional que se materializa o segundo link com a história da Epidemiologia da UFPel. O EPICOVID-19 indica marcantes desigualdades regionais, socioeconômicas e étnico-raciais ${ }^{3}$, o que não é novidade, para um grupo de pesquisadores que desde a década de 1980 se debruça sobre o tema das desigualdades em saúde.

Sigamos resistentes e resilientes para enfrentar essa pandemia.

Pedro Curi Hallal (https://orcid.org/0000-0003-1470-6461) ${ }^{1}$

${ }^{1}$ Programa de Pós-Graduação em Epidemiologia, Universidade Federal de Pelotas. Pelotas RS Brasil.

\section{Referências}

1. Hallal PC, Horta BL, Barros AJD, Dellagostin OA, Hartwig FP, Pellanda LC, Struchiner CJ, Burattini MN, Silveira MF, Menezes AMB, Barros FC, Victora CG. Evolução da prevalência de infecção por COVID-19 no Rio Grande do Sul, Brasil: inquéritos sorológicos seriados. Cien Saude Colet 2020; 25(Supl. 1):2395-2401.

2. Silveira MF, Barros AJD, Horta BL, Pellanda LC, Victora GD, Dellagostin OA, Struchiner CJ, Burattini MN, Valim ARM, Berlezi EM, Mesa JM, Ikeda MLR, Mesenburg MA, Mantesso M, Dall'Agnol MM, Bittencourt RA, Hartwig FP, Menezes AMB, Barros FC, Hallal PC, Victora CG. Nat Med 2020; PMID:32641783.

3. Hallal P, Hartwig F, Horta B, Victora GD, Silveira M, Struchiner C, Vidaletti LP, Neumann N, Pellanda LC, Dellagostin OA, Burattini MN, Menezes AM, Barros FC, Barros AJ, Victora CG. Remarkable variability in SARS-CoV-2 antibodies across Brazilian regions: nationwide serological household survey in 27 states. COVID-19 SARS-CoV-2 preprints from medRxiv and bioRxiv 2020; May 30. [acessado 2020 Jul 5]. Disponível em: https://www.medrxiv.org/content/10.1101/2020.05.30.20117531v1 